\title{
Morphine promotes the malignant biological behavior of non-small cell lung cancer cells through the MOR/Src/mTOR pathway
}

\author{
Xingyun Liu ${ }^{1 \dagger}$, Jia Yang ${ }^{2 \dagger}$, Chengwei Yang ${ }^{2}$, Xiang Huang ${ }^{2}$, Mingming Han ${ }^{2}$, Fang Kang ${ }^{2^{*}}$ and Juan $\mathrm{Li}^{1 *}$ (1)
}

\begin{abstract}
Background: Morphine, a $\mu$-opioid receptor (MOR) agonist, has been shown to be related to the activity of cancer cells, and a higher morphine dosage reduces the survival time of patients with lung cancer. However, the effect of morphine on the malignant behavior of lung cancer cells remains unclear. The aim of this study was to investigate the specific molecular mechanism by which morphine regulates the malignant biological behavior of non-small cell lung cancer.
\end{abstract}

Methods: Immunofluorescence staining and Western blot analyses were performed to detect MOR expression. H460 non-small cell lung cancer cells were used in this study, and cell proliferation, the cell cycle and apoptosis were evaluated using Cell Counting Kit-8 (CCK-8) and flow cytometry assays, respectively. Cell migration and invasion were detected using wound healing and Transwell assays. The effect of morphine on lung cancer development in vivo was examined by performing a xenograft tumor assay following morphine treatment.

Results: Morphine promoted the growth of $\mathrm{H} 460$ cells both in vivo and in vitro. Morphine enhanced cell migration and invasion, modified cell cycle progression through the $\mathrm{S} / \mathrm{G}_{2}$ transition and exerted an antiapoptotic effect on $\mathrm{H} 460$ cells. Additionally, morphine increased Rous sarcoma oncogene cellular homolog (Src) phosphorylation and activated the phosphoinositide 3 kinase (PI3K)/protein kinase B (AKT)/mammalian target of rapamycin (mTOR) pathway. Treatment with the MOR antagonist methylnaltrexone (MNTX) and the Src inhibitor protein phosphatase 1 (PP1) reduced the phosphorylation induced by morphine. Furthermore, MNTX, PP1, and the PI3K/AKT inhibitor deguelin reversed the antiapoptotic effect of morphine on lung cancer cells.

Conclusion: Morphine promotes the malignant biological behavior of H460 cells by activating the MOR and Src/ mTOR signaling pathways.

Keywords: Morphine, Non-small cell lung cancer, $\mu$-Opioid receptor, Malignant biological behavior, Src/mTOR

\footnotetext{
*Correspondence: 1561476059@qq.com; liuxingyun@stu.ahmu.edu.cn

${ }^{+}$Xingyun Liu and Jia Yang contributed equally to this work

${ }^{1}$ Department of Anesthesiology, Anhui Provincial Hospital Affiliated to Anhui Medical University, Hefei 230036, China

${ }^{2}$ Department of Anesthesiology, The First Affiliated Hospital of USTC, Division of Life Sciences and Medicine, University of Science and Technology of China, Hefei 230036, China
}

\section{Introduction}

Lung cancer is the second most common cancer worldwide and the leading cause of cancer-related mortality. More than 2 million new cases of lung cancer were reported worldwide in 2020, with at least 1.7 million patients dying from lung cancer [1, 2]. Non-small cell lung cancer (NSCLC) accounts for $85-90 \%$ of all cases, original author(s) and the source, provide a link to the Creative Commons licence, and indicate if changes were made. The images or other third party material in this article are included in the article's Creative Commons licence, unless indicated otherwise in a credit line to the material. If material is not included in the article's Creative Commons licence and your intended use is not permitted by statutory regulation or exceeds the permitted use, you will need to obtain permission directly from the copyright holder. To view a copy of this licence, visit http://creativecommons.org/licenses/by/4.0/. The Creative Commons Public Domain Dedication waiver (http://creativeco mmons.org/publicdomain/zero/1.0/) applies to the data made available in this article, unless otherwise stated in a credit line to the data. 
and the main treatment methods include surgery, radiation therapy, chemotherapy, and immunotherapy [3]. Radical resection is the only possible treatment for patients with lung cancer, but the prognosis of patients with advanced lung cancer is still poor. Morphine is a commonly used clinical drug for both surgical resection and pain treatment in patients with advanced lung cancer [4]. It exerts direct effects on the viability and migration of breast cancer cells. However, the mechanism underlying the effects of morphine on cancer cells remains unclear.

In a study of two different morphine administration regimens in patients with end-stage cancer, longer survival was observed for patients who received intraoperative intrathecal opioids than for those who received intravenous morphine administration, suggesting that a reduction in opioid use may delay tumor progression [5]. Maher retrospectively analyzed 99 patients with nonsmall cell lung cancer who underwent video-assisted thoracoscopic surgery with lobectomy and found that the recurrence rate of patients within 5 years after lung cancer surgery was positively correlated with the dose of opioid receptor agonists administered during the operation and within $96 \mathrm{~h}$ after the operation [6]. In vitro, morphine inhibits the activity and growth of HSC-3 oral cancer cells by inhibiting vascular endothelial growth factor [7] and reduces the growth of MCF-7 breast cancer cells by blocking the cell cycle [8]. However, morphine has been reported to promote tumor cell proliferation by upregulating miR-543 expression in vitro [9]. Therefore, morphine exerts a polarizing effect on tumor cells, but the underlying mechanism remains unclear $[10,11]$.

Opioid receptors are divided into three subtypes, $\mu$-opioid receptor (MOR), $\mathrm{k}$-opioid receptor (KOR), and $\delta$-opioid receptor (DOR), among which MOR is the main receptor for commonly used drugs, such as morphine and fentanyl [12]. Further research on the function of MOR showed upregulated MOR expression in the tumor tissues from patients with prostate cancer and that high MOR expression was positively correlated with the metastasis of prostate cancer [13]. Similar results were obtained from studies of esophageal and laryngeal squamous cell carcinoma [14, 15]. Singleton et al. analyzed the clinical specimens from 34 patients with lung cancer and found twofold higher MOR expression in lung cancer tissue than that in adjacent normal lung tissue [16]. The MOR-specific antagonist methylnaltrexone (MNTX) reduces the viability of lung cancer cells by inhibiting Src activation [17].
Mammalian target of rapamycin, mTOR, is typically upregulated in tumor cells to induce proliferation [18]. Phosphoinositide 3 kinase (PI3K)/protein kinase B (AKT), components upstream of mTOR, play important regulatory roles in mTOR activation, and the PI3K/AKT/ mTOR signaling pathway is an important downstream target of the Rous sarcoma oncogene cellular homolog (Src) signal transduction pathway [19]. Activation of upstream PI3K/AKT signaling further activates mTOR to promote the growth and division of tumor cells by inducing microtubule growth and other activities [20, 21]. Protein phosphatase 1 (PP1), a specific and effective Src inhibitor, has been shown to bind protein $4.1 \mathrm{~N}$ and positively regulates its activity. This complex was reported to inactivate the c-Jun $\mathrm{N}$-terminal kinase (JNK) pathway, a signaling cascade with important roles in cancer pathogenesis, thus inhibiting lung cancer progression [22]. PP1 inhibits $\mathrm{C}-\mathrm{X}-\mathrm{C}$ chemokine receptor 7 (CXCR7)-induced Src phosphorylation and the AKT/mTOR pathway, which inhibits the proliferation of different melanoma cell lines $[23,24]$. Deguelin, a naturally occurring rotenoid of the flavonoid family, is an AKT inhibitor with chemopreventive activities that exerts antitumor effects on several cancers. Deguelin impedes carcinogenesis by (1) inducing cell apoptosis, (2) inhibiting tumor cell propagation, and (3) preventing the malignant transformation of tumors through the PI3K/AKT and NF-KB signaling pathways in human lung cancer cells [25-27]. Thus, our current study is the first to determine whether morphine inhibits the growth of $\mathrm{H} 460$ cells and regulates apoptosis and the cell cycle in vitro and in vivo. In addition, additional experiments were conducted to investigate whether morphine induces changes in malignant biological behavior through the MOR/Src pathway and to clarify the role of the PI3K/AKT/mTOR signaling pathway in the regulation of $\mathrm{H} 460$ cells by morphine.

\section{Materials and methods Materials}

Morphine was purchased from Northeast Pharmaceutical Group Shenyang First Pharmaceutical Co., Ltd. (24265669-4, Shenyang, China). The following kits, reagents and proteins were used: a BCA protein assay kit (Sigma-Aldrich); RPMI-1640 (HyClone, USA); DMEM (HyClone, USA); fetal bovine serum (Gibco, USA); trypsin (Gibco, USA); Cell Counting Kit-8 (CCK-8) (TargetMol, USA); methylnaltrexone bromide (TargetMol, USA); the Src inhibitor PP1 (TargetMol, USA); the PI3K/ AKT inhibitor deguelin (TargetMol, USA); anti-phospho-Src (Y419; BM4307, BOESTER, China); anti-Src 
(BM4873, BOESTER, China); anti-phospho-PI3K p85 (Tyr607; YP0765, ImmunoWay, China); anti-PI3K p85 (60225-1-Ig, Proteintech, China); anti-phospho-AKT (Ser473; 66444-1-AP, Proteintech, China); anti-AKT (10176-2-AP, Proteintech, China); anti-phospho-mTOR (Ser2448; 67778-1-Ig, Proteintech, China), anti-mTOR (66888-1-Ig, Proteintech, China), anti-MOR (ab10275, Abcam, UK); anti-GAPDH (ab9385, Abcam, UK); Matrigel (Corning, USA), anti-BCL2 (60178-1-Ig, Proteintech, China); anti-BAX (60267-1-Ig, Proteintech, China); anti-cleaved Caspase-9 (ab2324, Abcam, UK); anti-cleaved Caspase-3 (ab2302, Abcam, UK); and anticleaved polyADP-ribose polymerase (PARP) (66520-1Ig, Proteintech, China). Balb/c female nude mice aged 4-6 weeks were purchased from the Experimental Animal Center of Anhui Provincial Hospital.

\section{Cell culture}

H460 human non-small cell lung cancer cells and BEAS2B human normal lung epithelial cells were purchased from the National Collection of Authenticated Cell Culture. H460 cells were cultured in RPMI-1640 containing $10 \%$ fetal bovine serum, $100 \mathrm{U} / \mathrm{ml}$ penicillin, and $100 \mathrm{mg} /$ $\mathrm{ml}$ streptomycin at $37^{\circ} \mathrm{C}$ in an environment containing $5 \% \mathrm{CO}_{2}$. BEAS-2B cells were cultured in DMEM containing $10 \%$ fetal bovine serum, $100 \mathrm{U} / \mathrm{ml}$ penicillin, and $100 \mathrm{mg} / \mathrm{ml}$ streptomycin at $37^{\circ} \mathrm{C}$ in an environment containing $5 \% \mathrm{CO}_{2}$. Morphine was dissolved in normal saline (NS) and diluted to several concentrations. MNTX, PP1, and deguelin were dissolved in dimethyl sulfoxide (DMSO) and diluted to several concentrations. Additionally, cells were pretreated with $0.1 \mu \mathrm{g} / \mu \mathrm{l}$ morphine, $0.1 \mu \mathrm{g} / \mu \mathrm{l}$ MNTX, $5 \mu \mathrm{M}$ PP1, or $1 \mu \mathrm{M}$ deguelin to investigate the mechanisms underlying morphine-induced malignant biological behavior. Cells in the normal control group were cultured with RPMI-1640 medium, NS, or DMSO.

\section{Cell viability assay}

H460 cells were inoculated in 96-well plates at a density of $2 \times 10^{3}$ cells/well. Six replicate wells were prepared for each group. Cells were cultured at $37^{\circ} \mathrm{C}$ for $48 \mathrm{~h}$. The supernatant was removed, and $10 \mu \mathrm{l}$ of CCK-8 reagent were added. Then, the cells were incubated in the dark for $1 \mathrm{~h}$, a standard instrument (Thermo Fisher, Finland) was used to detect the OD at a wavelength of $450 \mathrm{~nm}$, and cell viability was calculated. Each experiment was repeated at least three times.

\section{Tumor xenograft experiment}

Four- to six-week-old female Balb/c nude mice were randomly assigned to control and treatment groups. All mice received a subcutaneous injection of $5 \times 10^{6}$ cells (100 $\mu \mathrm{l}$ of cell suspension) in the back. The treatment groups were subcutaneously injected with morphine $(1.5 \mathrm{mg} / \mathrm{kg})$ every other day for 3 weeks based on the results of our preliminary experiment, while the control group received an intraperitoneal injection of NS in the same manner. Tumor growth was observed weekly for 4 weeks. Tumor size was measured using a ruler after treatment. On Day 28, the nude mice were sacrificed, and tumor tissues were isolated and weighed. The tumor volume was calculated using the following formula: volume $\left(\mathrm{mm}^{3}\right)=1 / 2 \times($ length $\times$ width $\times$ width $)$.

\section{Flow cytometry}

Flow cytometry assays were conducted as previously described [7]. Cells were plated into 6-well plates at a density of $3 \times 10^{5}$ cells/well and then incubated with different concentrations of morphine, MNTX, deguelin, or PP1 for $48 \mathrm{~h}$. The treated cells were collected and washed with PBS, resuspended in $500 \mu \mathrm{l}$ of $1 \times$ binding buffer, and stained with $5 \mu \mathrm{l}$ of annexin V-FITC (AV) and $7 \mu \mathrm{l}$ of propidium iodide (PI) for $15 \mathrm{~min}$ at $4{ }^{\circ} \mathrm{C}$ in the dark. Then, the samples were analyzed using flow cytometry (Agilent NovoCyte, Santa Clara, CA, USA). For the cell cycle analysis, cells were harvested, washed with PBS two times, and then fixed with $70 \%$ ethanol overnight at $4{ }^{\circ} \mathrm{C}$. Cells were counterstained with $50 \mu \mathrm{g} / \mathrm{mL}$ PI and $0.1 \%$ ribonuclease A (RNase A) in $400 \mu \mathrm{L}$ of PBS at room temperature in the dark for $30 \mathrm{~min}$. Stained cells were assayed and quantified using flow cytometry (Agilent NovoCyte, Santa Clara, CA, USA). The proliferation index $(\mathrm{PI})=(\mathrm{S}+\mathrm{G} 2 / \mathrm{M}) /(\mathrm{G} 0 / 1+\mathrm{S}+\mathrm{G} 2 / \mathrm{M}) \times 100 \%$. Each experiment was repeated at least three times.

\section{Wound-healing assay}

Wound-healing assays were conducted as previously described [11]. Cell migration was assessed using a wound-healing assay. Cells were cultured in 6-well plates at a density of $5 \times 10^{5}$ cells/well and allowed to grow until reaching 95\% confluence. A "wound" was created by scratching the cell monolayer with a $200-\mu \mathrm{L}$ pipette tip. Then, the cells were cultured with morphine in serum-free medium for $24 \mathrm{~h}$. Images of the wounds were captured at 0 and $24 \mathrm{~h}$ (Olympus, Tokyo, Japan). The migration distance was analyzed with ImageJ software. Each experiment was repeated at least three times. 


\section{Transwell assay}

Transwell assays were conducted as previously described [22]. The effect of morphine on the migration and invasion of H460 cells was evaluated using Transwell chambers. The chambers were placed in a 24-well culture dish, and $5 \times 10^{4} \mathrm{H} 460$ cells resuspended in $100 \mu \mathrm{L}$ of serumfree medium were then seeded into the upper compartments containing either uncoated or Matrigel-coated membranes. After an incubation for $48 \mathrm{~h}$, the compartments were removed for cleaning, and cells on the lower surface were fixed with methanol and stained with crystal violet. Migration and invasion were assessed by counting the migrated cells on the lower surface under a microscope (Olympus, Tokyo, Japan). The cells were imaged at $100 \times$ magnification and 5 randomly recorded visual fields were captured at $400 \times$ magnification. Each experiment was repeated at least three times.

\section{Western blot assay}

Western blot assays were conducted as previously described [17]. After H460 cells were treated with morphine for $48 \mathrm{~h}$, the collected samples were washed with cold PBS. Then, the cells were lysed in the lysis buffer. After an incubation for $30 \mathrm{~min}$ at $4{ }^{\circ} \mathrm{C}$, the samples were centrifuged at $15,000 \mathrm{rpm}$ for $15 \mathrm{~min}$ at $4{ }^{\circ} \mathrm{C}$, and the supernatants were collected to determine the protein concentration using a BCA protein assay kit (SigmaAldrich). The supernatants of cell homogenates ( $40 \mu \mathrm{g}$ of protein equivalent in each sample) were boiled at $100{ }^{\circ} \mathrm{C}$ in sample buffer (P0015L, Beyotime, China) for $5 \mathrm{~min}$. The cell extracts were separated on 10\% SDS-PAGE gels and transferred to PVDF membranes; membranes were blocked with 5\% BSA in TBST. Western blot analyses were performed using primary antibody solutions according to the manufacturer's instructions. Then, the cells were washed three times with TBST and incubated with secondary antibodies for $1 \mathrm{~h}$ at room temperature. The protein bands were detected using the ECL chemiluminescence system. Each experiment was repeated at least three times.

\section{Immunofluorescence staining}

Immunofluorescence assays were conducted as previously described [22]. After growing on coverslips, the cells in 24-well plates cultured at a density of $5 \times 10^{4}$ cells/well were fixed with $4 \%$ paraformaldehyde for $20 \mathrm{~min}$, and then, the cells were permeabilized with $0.5 \%$ Triton X-100 (Solarbio, Beijing, China) for $20 \mathrm{~min}$ at room temperature. Cells were blocked with normal goat serum (Solarbio, China) for $30 \mathrm{~min}$ at $37^{\circ} \mathrm{C}$ and then incubated overnight at $4{ }^{\circ} \mathrm{C}$ with the primary anti-MOR antibody (1:100, Abcam, USA). Then, cells were incubated for $1 \mathrm{~h}$ at $37^{\circ} \mathrm{C}$ with $\mathrm{Cy} 3$-conjugated goat anti-rabbit IgG (Beyotime, China) as the secondary antibody. The nuclei were stained with DAPI (Sangon Biotech, China) for 5 min after washes with PBS. Images were captured using a confocal microscope (Olympus, Tokyo, Japan). Each experiment was repeated at least three times.

\section{Statistical analysis}

The data are presented as the means \pm the standard errors of the means. The statistical analyses were performed using paired or unpaired Student's t-tests, followed by Tukey's multiple comparison post hoc test, as appropriate. Some data with a normal distribution were analyzed using one-way ANOVA and are presented as the means \pm standard deviations. $\mathrm{P}<0.05$ was considered to indicate a statistically significant difference. GraphPad Prism software (version 8, GraphPad Software, San Diego, CA, USA) was used to calculate statistics and plot the results.

\section{Results \\ Morphine promotes the proliferation, migration and invasion of $\mathrm{H} 460$ cells}

We investigated whether MOR is expressed in nonsmall cell lung cancer (NSCLC) by performing immunofluorescence staining to determine the widespread distribution of MOR in BEAS-2B and $\mathrm{H} 460$ cells (Fig. 1a). Moreover, Western blot assays revealed significantly increased MOR expression in H460 cells compared with BEAS-2B cells (Fig. 1b). According to a preliminary experiment and previous results[28], we then treated $\mathrm{H} 460$ cells with morphine and the MOR antagonist MNTX for $48 \mathrm{~h}$ and found that $0.1 \mu \mathrm{g} / \mu \mathrm{L}$ morphine promoted the proliferation of $\mathrm{H} 460$ cells, while the effect of $0.1 \mu \mathrm{g} / \mu \mathrm{L}$ MNTX on the proliferation of $\mathrm{H} 460$ cells was not significant (Fig. 1c and d). When morphine and MNTX were applied at concentrations of $1.0 \mu \mathrm{g} / \mu \mathrm{L}$, the cellular activity of the two groups was significantly inhibited (Fig. 1d), consistent with the results of previous research [10]. Subsequently, the effects of $0.1 \mu \mathrm{g} / \mu \mathrm{L}$ morphine on the migration and invasion of $\mathrm{H} 460$ cells were verified by performing wound-healing and Transwell assays. The scratch 


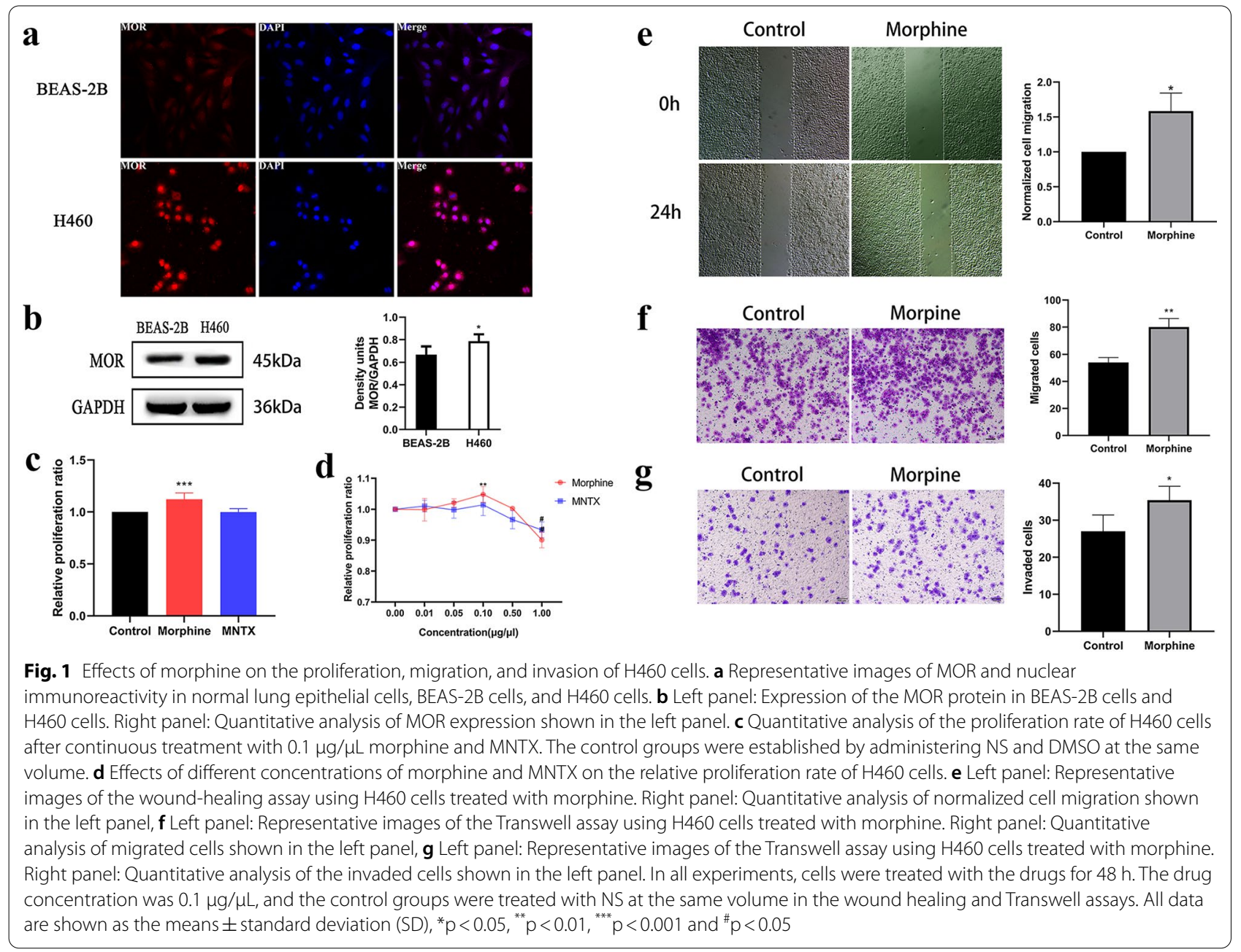

test showed that morphine significantly increased the migration of H460 cells after $24 \mathrm{~h}$ (Fig. 1e). Moreover, the Transwell assay showed that morphine increased the migration and invasion of $\mathrm{H} 460$ cells (Fig. 1f and g) after $48 \mathrm{~h}$ in vitro.

\section{Morphine inhibits the population of cells in G2 phase and the apoptosis of $\mathrm{H} 460$ cells}

We next measured the effect of morphine on the cell cycle using flow cytometry (Fig. 2a). The population of cells in G2 phase was significantly reduced in the morphine group and a dramatic increase in the number of cells in S phase was observed compared with the control group (Fig. 2b). We next measured the effect of morphine on cell apoptosis using flow cytometry (Fig. 2c), and the population of apoptotic cells in the morphine group was significantly reduced compared with that in the control group (Fig. 2d). In addition, the expression of Bcl-2 protein in the morphine group was increased, while the levels of Bax, cleaved Caspase-3, cleaved Caspase-9, and cleaved PARP were decreased (Fig. 2e). These data collectively suggested that morphine affected cell cycle progression through the S/G2 transition and inhibited the apoptosis of $\mathrm{H} 460$ cells.

\section{Morphine activates the Src/PI3K/AKT/mTOR signaling pathway}

The PI3K/AKT/mTOR signaling pathway is involved in the mechanism regulating cell proliferation. We 
$\mathbf{a}$

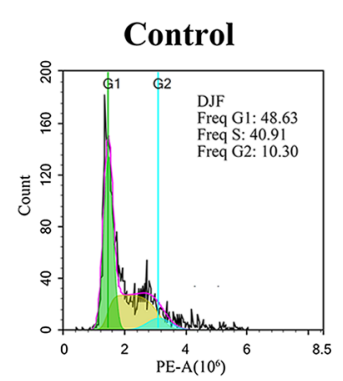

c

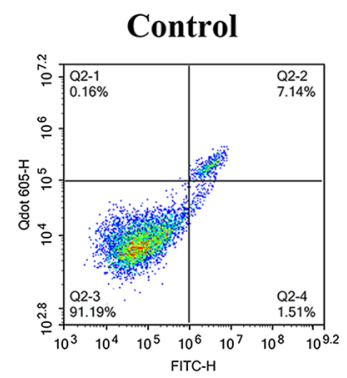

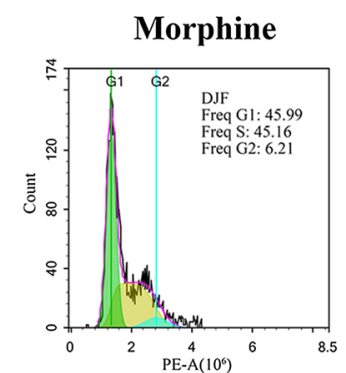

Morphine

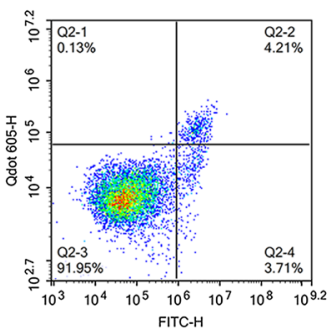

b

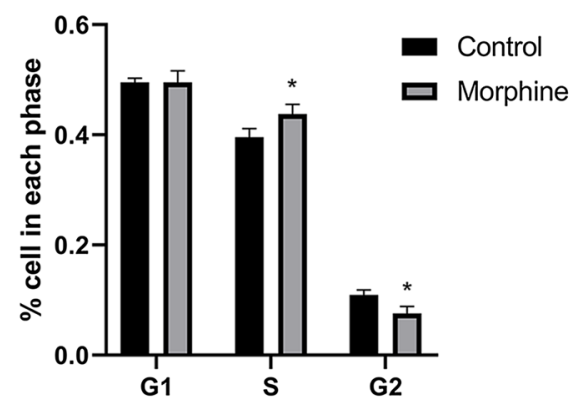

d

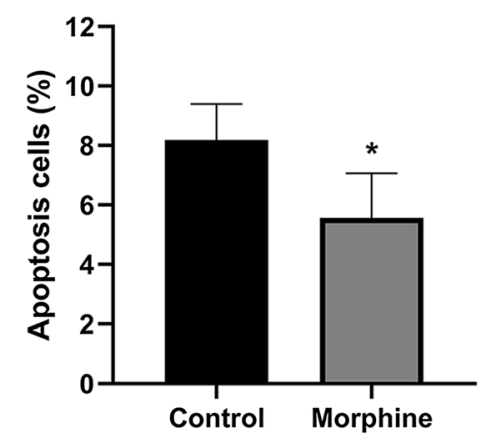

$\mathbf{e}$
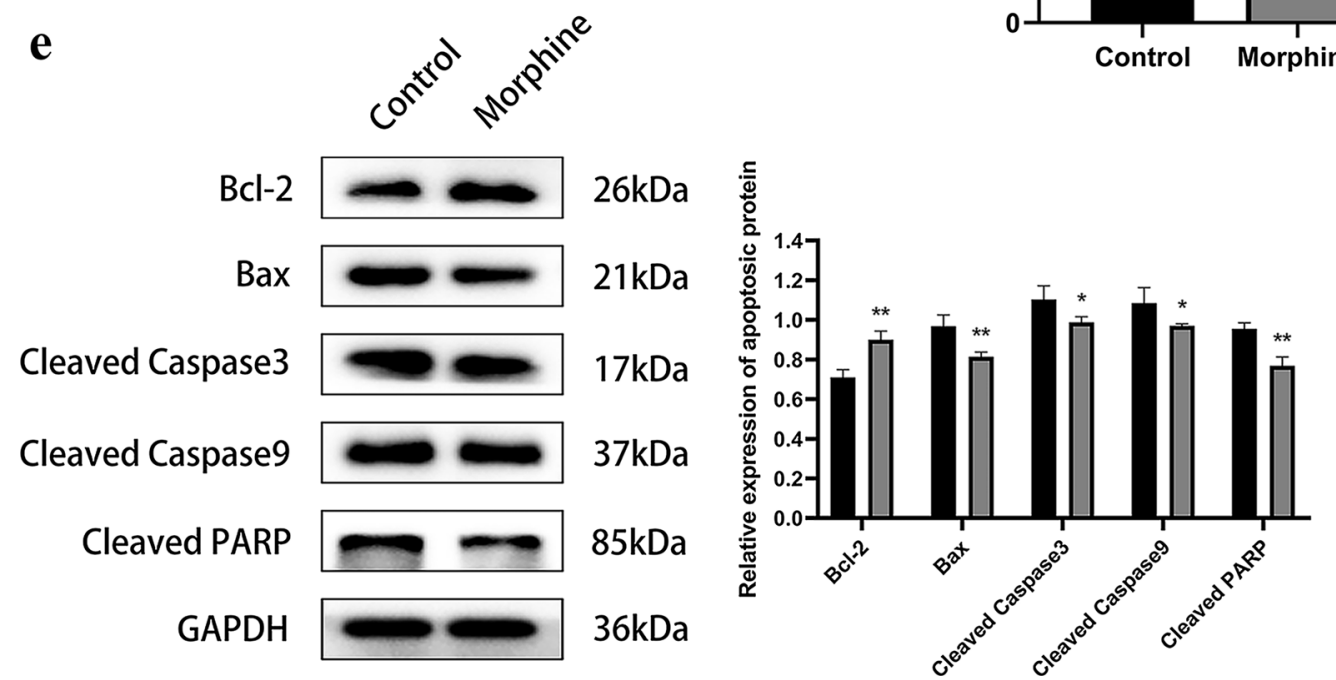

Fig. 2 Morphine promotes cell cycle progression through the $G_{1} / S$ transition and inhibits apoptosis in $H 460$ cells. a Flow cytometry was used to detect the effect of morphine on the cell cycle of $\mathrm{H} 460$ cells. $\mathbf{b}$ Quantitative analysis of the population of cells in each phase shown in (a) c AV/PI flow cytometry was used to detect the effect of morphine on the apoptosis of H460 cells. $\mathbf{d}$ Quantitative analysis of the apoptotic cells shown in (c). e Left panel: Levels of BCl-2, Bax, cleaved Caspase-3, cleaved Caspase-9, and cleaved PARP were analyzed using Western blotting. Right panel: Quantitative analysis of apoptosis-related protein expression shown in the left panel. $\mathrm{H} 460$ cells were treated with $0.1 \mu \mathrm{g} / \mu \mathrm{L}$ morphine for $48 \mathrm{~h}$, and the control group was treated with NS at the same volume. All data are shown as the means $\pm S D,{ }^{*} p<0.05,{ }^{* *} p<0.01$

indicated the potential relationship between the morphine-induced increase in malignant biological behavior and the Src/PI3K/AKT/mTOR pathway through Western blot assays (Fig. 3a). Compared with the levels in the control groups, the levels of Src and AKT phosphorylation were increased in the morphine group (Fig. 3b and d), along with the activation of PI3K and mTOR (Fig. 3c and e). This result proved that morphine activated the Src/PI3K/AKT/mTOR signaling pathway, consistent with the results of previous investigations of malignant cell behavior. Thus, morphine 


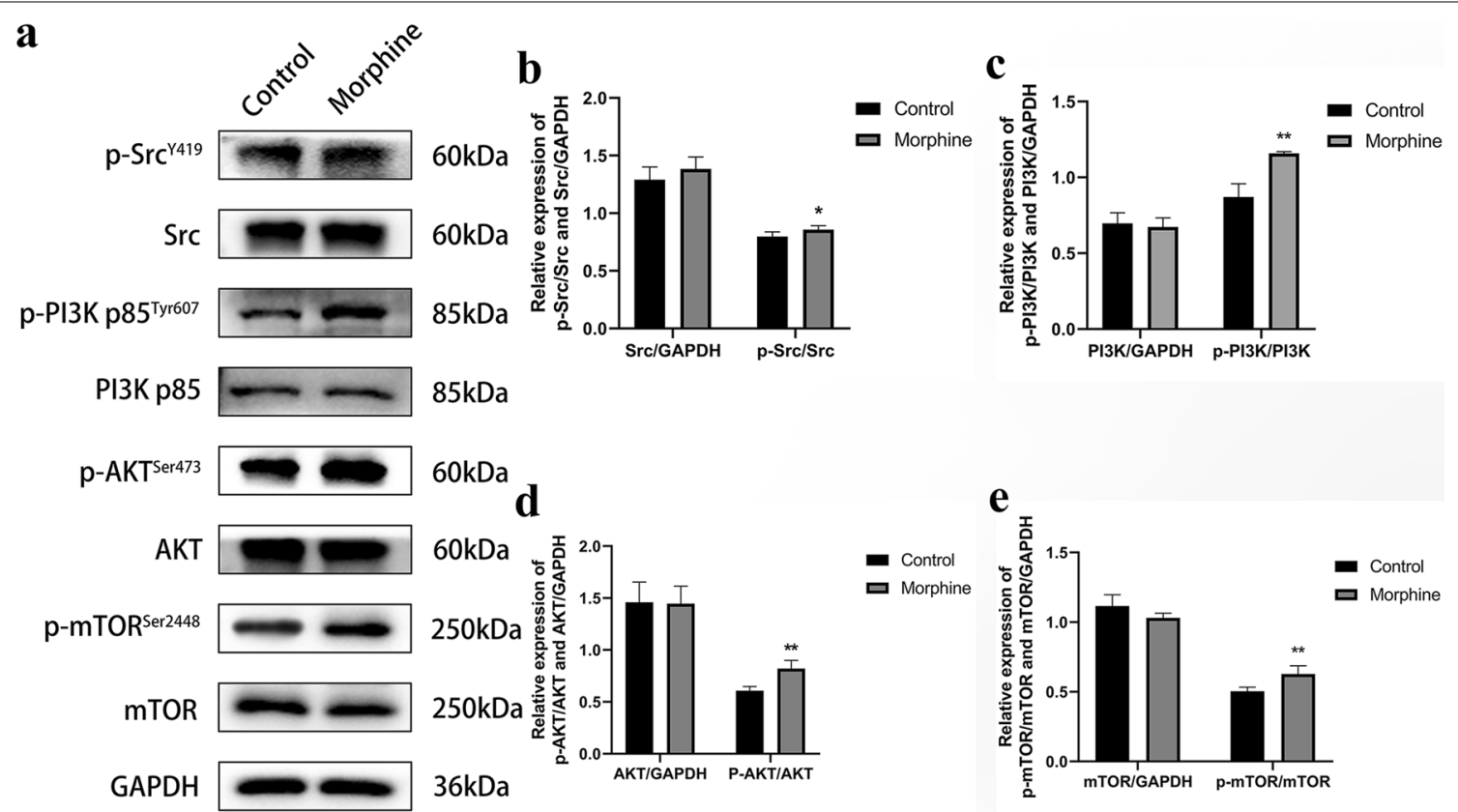

Fig. 3 Morphine activates Src kinase and PI3K/AKT/mTOR signaling in vitro. a Levels of the total and phosphorylated Src, PI3K, AKT, and mTOR proteins in $\mathrm{H} 460$ non-small cell lung cancer cells treated with $0.1 \mu \mathrm{g} / \mu \mathrm{L}$ morphine for $48 \mathrm{~h}$. b Quantitative analysis of Src and phospho-Src levels. c Quantitative analysis of PI3K and phospho-PI3K levels. d Quantitative analysis of AKT and phospho-AKT levels. e Quantitative analysis of mTOR and phospho-mTOR levels. All data are presented as the means $\pm S D,{ }^{*} p<0.05,{ }^{* *} p<0.01$

may participate in the induction of cell proliferation, migration, and invasion and inhibition of cell apoptosis through the Src/PI3K/AKT/mTOR signaling pathway.

\section{MOR and Src inhibitors antagonize the morphine-induced proliferation, migration, and invasion of $\mathrm{H} 460$ cells}

We treated H460 cells with the MOR antagonist MNTX and the Src inhibitor PP1 to investigate the effect of MOR and Src on the malignant behavior of $\mathrm{H} 460$ cells, and the concentration of PP1 was determined using the method described in a previous study [18]. Compared with the control, MNTX significantly inhibited the morphineinduced proliferation of $\mathrm{H} 460$ cells (Fig. 4c), and PP1 also exerted obvious inhibitory effects on the proliferation of H460 cells (Fig. 4c). We further explored the effects of MNTX and Src on morphine-induced migration and invasion by performing Transwell migration and invasion experiments (Fig. 4a and d). A quantitative analysis showed that MNTX and PP1 inhibited the migration and invasion of $\mathrm{H} 460$ cells treated with morphine compared with the control (Fig. $4 \mathrm{~b}$ and e). Overall, these data indicated that morphine promoted the proliferation, migration, and invasion of $\mathrm{H} 460$ cells through the MOR and Src pathways.
MNTX and PP1 inhibit the morphine-induced activation of the Src/PI3K/AKT/mTOR signaling pathway

First, we performed Western blot analyses to explore the functions of MNTX and PP1 in the Src/PI3K/AKT/ mTOR signaling pathway (Fig. 5a). Compared with the control group, MNTX plus morphine inhibited the activation of Src and mTOR (Fig. 5b and e) and more obviously inhibited the activation of PI3K and AKT (Fig. 5c and d). The inhibitory effect of PP1 plus morphine on the activation of the $\mathrm{Src} / \mathrm{PI} 3 \mathrm{~K} / \mathrm{AKT} / \mathrm{mTOR}$ signaling pathway was basically the same (Fig. 5b-e). Second, compared with the effect of morphine, MNTX and PP1 significantly inhibited the morphine-induce activation of the Src/ PI3K/AKT/mTOR pathway (Fig. 5b-e). Based on this result, pharmacological blockade of MOR and Src inhibited the effect of morphine on activating the Src/PI3K/ AKT/mTOR pathway.

\section{Blockade of MOR and Src/PI3K/AKT/mTOR pathways inhibit the cell cycle progression and antiapoptotic effects of morphine}

Flow cytometry has previously shown that morphine inhibits apoptosis, while $1 \mu \mathrm{M}$ deguelin induces apoptosis by blocking PI3K/AKT signaling [19] and results in cell cycle arrest [29]. In our study, flow cytometry showed 
a

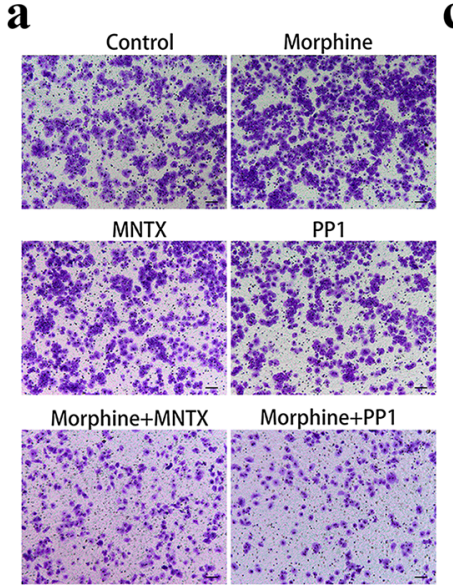

b

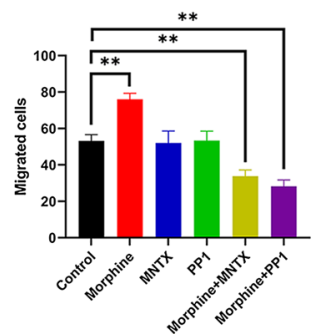

c

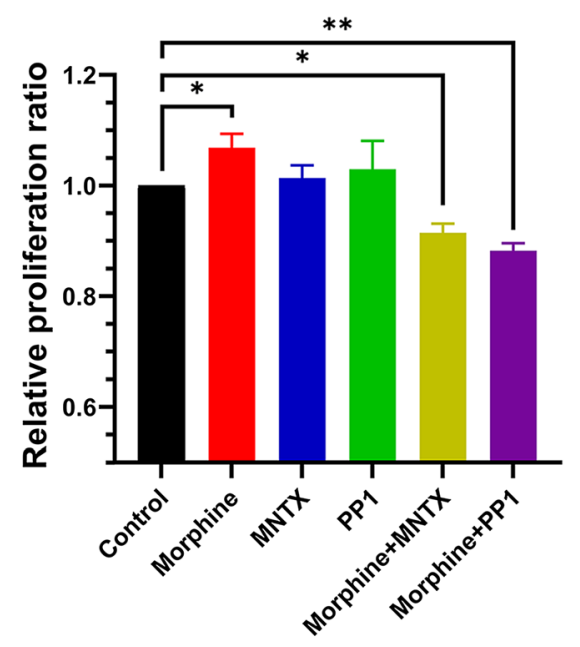

d

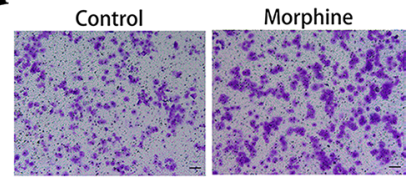

PP1

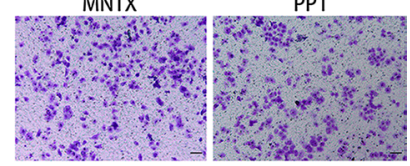

Morphine+MNTX_Morphine+PP1

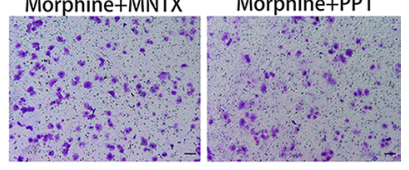

$\mathbf{e}$

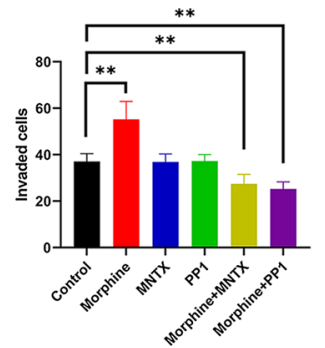

Fig. 4 Effects of inhibitors on the proliferation, migration, and invasion of H460 cells. a Representative images from the Transwell assay using H460 cells treated with morphine and inhibitors. b Quantitative analysis of migrated cells. c Quantitative analysis of the proliferation rate of $\mathrm{H} 460$ cells after continuous treatment with morphine and inhibitors. $\mathbf{d}$ Representative images of the Transwell assay with $\mathrm{H} 460$ cells that were treated with morphine and inhibitors. e Quantitative analysis of invaded cells shown in the preceding panel. In all experiments, cells were treated with the drugs for $48 \mathrm{~h}$. The concentrations of morphine and MNTX were $0.1 \mu \mathrm{g} / \mu \mathrm{L}$, the concentration of PP1 was $5 \mu \mathrm{M}$, and the control groups were treated with NS and DMSO at the same volumes. All data are presented as the means $\pm S D,{ }^{*} p<0.05,{ }^{* *} p<0.01$

that groups treated with the inhibitors plus morphine exhibited an inhibition of cell cycle progression compared with the morphine group (Fig. 6a and b). In addition, no significant difference in the proliferation index was observed between the groups that were treated with the inhibitors and the control group. The MNTX plus morphine group exhibited a significant increase in $\mathrm{H} 460$ cell apoptosis compared with the morphine treatment group, and the effect was similar to that of deguelin plus morphine (Fig. $6 \mathrm{c}$ and d). However, no significant differences were observed between the treatment groups and the control group. The population of apoptotic cells in the PP1 plus morphine group was significantly higher than that in the morphine group (Fig. 6d), indicating that PP1 antagonized the antiapoptotic effect of morphine. Additionally, Western blot analysis showed that H460 cells treated with MNTX, PP1, and deguelin alone and in combination with morphine separately exhibited a decreased $\mathrm{Bcl} 2 / \mathrm{Bax}$ protein ratio (Fig. 6f) and increased levels of the cleaved Caspase-3, cleaved Caspase-9, and cleaved PARP proteins (Fig. 6g-i). Therefore, blocking the MOR and Src/PI3K/Akt/mTOR pathways with these drugs inhibited the antiapoptotic effect of morphine, suggesting that morphine modulates apoptosis through the MOR and Src/PI3K/AKT pathways.

\section{Morphine promotes tumor growth by activating the Src/ $\mathrm{PI} 3 \mathrm{~K} / \mathrm{AKT} / \mathrm{mTOR}$ pathway in nude mice}

Adult female nude mice aged 4-6 weeks were selected for the tumor formation experiment. The nude mice were divided into 2 groups and subcutaneously injected with morphine and NS on the 7th day. The tumor size in the morphine group was significantly larger than that in the control group on the 28th day (Figs. 7a-c). Western blot analysis confirmed significantly higher activity of the $\mathrm{Src} / \mathrm{PI} 3 \mathrm{~K} / \mathrm{AKT} / \mathrm{mTOR}$ pathway in the morphine group than that in the control group (Figs. $7 d-h$ ). These results clearly reveal that morphine promotes tumor growth and stimulates Src/PI3K/AKT/mTOR signaling in vivo. 

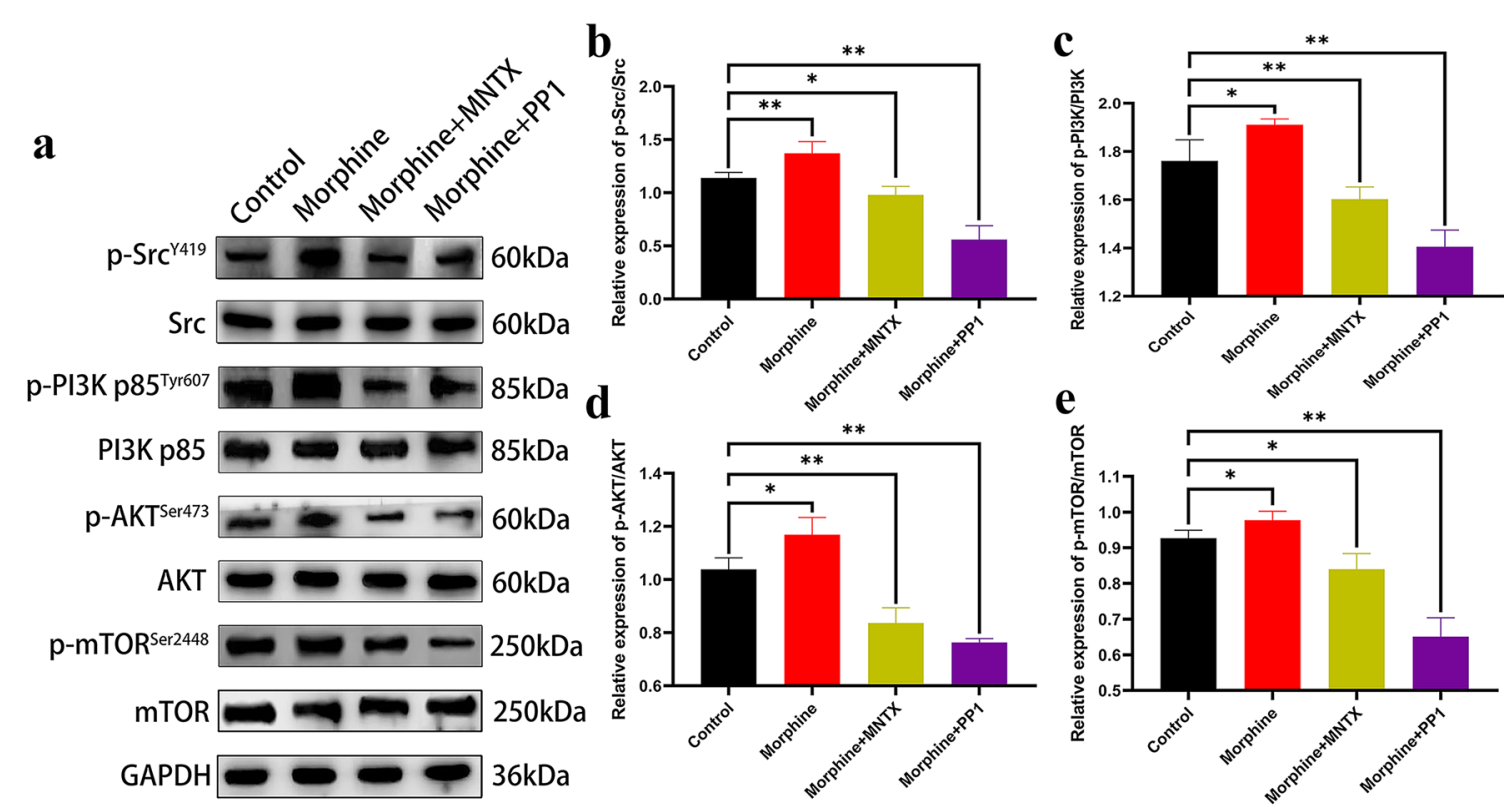

Fig. 5 MNTX and PP1 inhibit the morphine-induced activation of the Src/PI3K/AKT/mTOR signaling pathway. a Levels of total and phosphorylated Src, PI3K, AKT, and mTOR proteins in H460 non-small cell lung cancer cells treated with drugs. b Quantitative analysis of phospho-Src levels normalized to Src levels. c Quantitative analysis of phospho-PI3K levels normalized to PI3K levels. d Quantitative analysis of phospho-AKT levels normalized to AKT levels. e Quantitative analysis of phospho-mTOR levels normalized to mTOR levels, as shown in (a). In all experiments, cells were treated with the drugs for $48 \mathrm{~h}$. The concentrations of morphine and MNTX were $0.1 \mu \mathrm{g} / \mu \mathrm{L}$, the concentration of PP1 was $5 \mu \mathrm{M}$, and the control groups were treated with NS and DMSO at the same volumes. All data are presented as the means $\pm S D,{ }^{*} p<0.05,{ }^{* *} p<0.01$

\section{Discussion}

In 1986, the World Health Organization proposed a three-step therapy for cancer pain; nonopioid drugs were recommended for mild pain, weak opioid drugs were recommended for moderate pain, and strong opioid drugs were recommended for severe pain. Morphine is still one of the most commonly used opioid drugs [30]. In recent years, morphine has been shown to exert different effects on different tumor cells. J Nguyen showed that morphine did not affect tumorigenesis but promoted the growth of existing tumors and reduced the overall survival rate of mice, and morphine-induced cancer progression may be related to MOR [31]. We found that a low concentration of morphine promotes the malignant biological behavior of H460 non-small cell lung cancer cells in vitro, consistent with previous studies [10,32]. Other studies have shown that the inhibitory effect of a millimolar concentration of morphine on angiogenesis may be due to its cytotoxicity at this concentration [33,34]. However, morphine promotes angiogenesis when its concentration in plasma reaches only a level ranging from $2 \mathrm{nM}$ to $3.5 \mathrm{nM}$ $[35,36]$. Therefore, we speculate that the inhibitory effect induced by high concentrations of morphine on cells in this experiment was due to its cytotoxicity [37]. As shown in our study, morphine promoted the proliferation of H460 non-small cell lung cancer cells through MOR and significantly increased tumor size in nude mice in vivo, similar to the results obtained by K Gupta et al. [28]. At the same time, we found that morphine can increase the number of cells in $\mathrm{S}$ phase and decrease the population of cells in G2 phase, which proves that morphine can block the transition of cells from $S$ to $G 2$ phase, but there is no significant difference in PI, indicating that morphine does not promote cell proliferation through affecting the cell cycle in $\mathrm{H} 460$ cells. In addition, as expected, morphine significantly inhibited the apoptosis of $\mathrm{H} 460$ cells, increased the Bcl-2/Bax ratio, and significantly decreased Caspase protein expression. Based on these results, morphine inhibits $\mathrm{H} 460$ cell apoptosis mainly through the mitochondrial pathway.

$\mathrm{Src}$ is an intracytoplasmic tyrosine-specific protein kinase that binds to the cytoplasmic surface of the plasma membrane. When cells are activated by external stimuli (such as growth factors, cytokines, steroid hormones, and drugs that act on G-protein-coupled and adhesion protein receptors), they initiate a signaling cascade that activates Src to produce a wide range of effects [38, 39]. The degree of Src activation is an independent predictor 


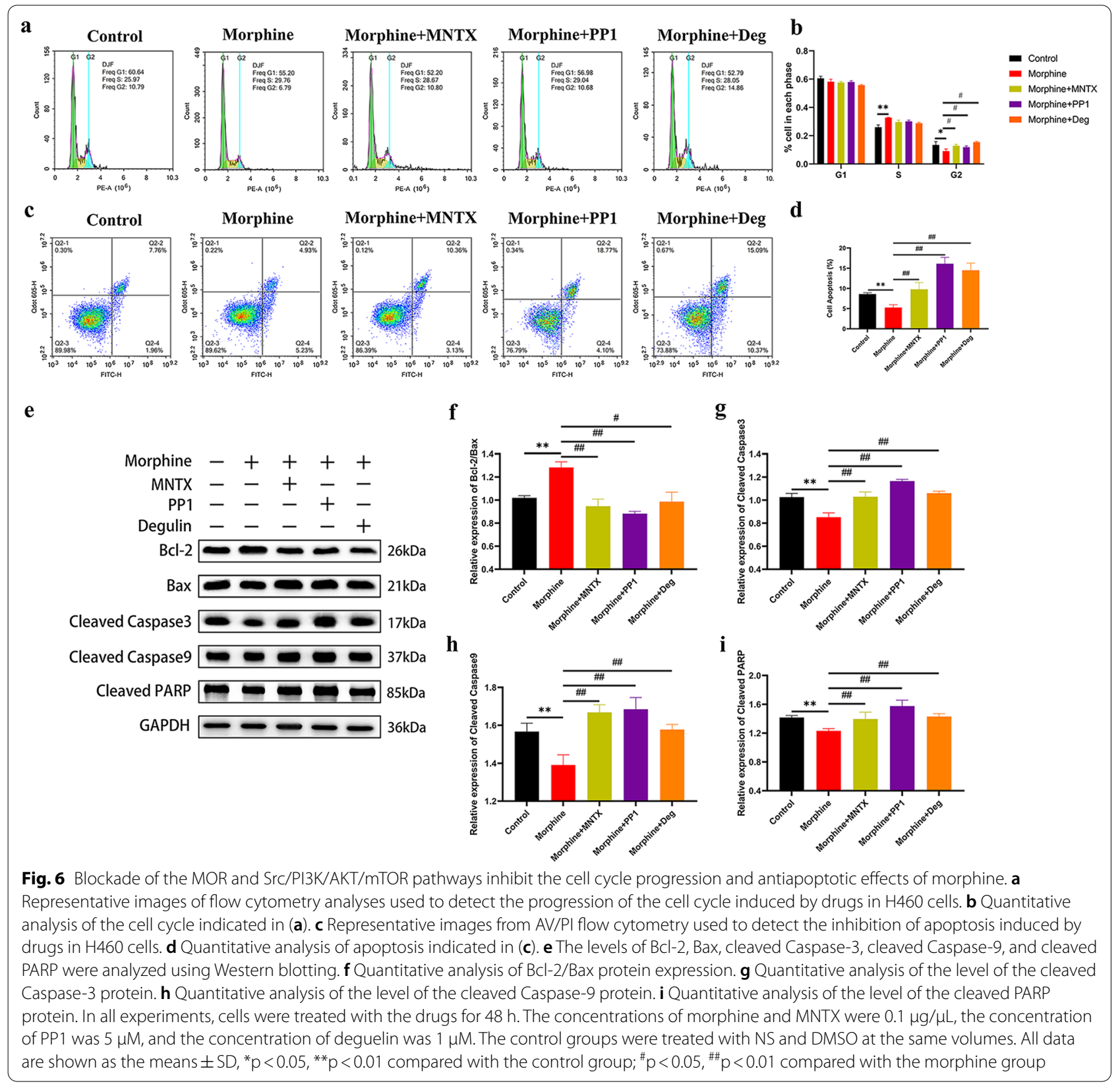

of the prognosis of patients with laryngeal cancer. The greater the degree of Src activation, the higher the level of p-Src (Tyr419), which indicates a worse prognosis for patients with laryngeal carcinoma [40]. Similar conclusions were reported for malignant pleural mesothelioma and hepatocellular carcinoma [41, 42]. PI3K is an intracellular phosphatidylinositol kinase. AKT, also known as protein kinase $\mathrm{B}$, is an important downstream target of the PI3K signal transduction pathway. mTOR is a serine/ threonine protein kinase and a downstream effector of PI3K/AKT. P-PI3K p85 (Tyr607), p-AKT (Ser473), and p-mTOR (Ser2448) have been shown to be related to the biological behavior of tumor cells [43-45]. Therefore, the 


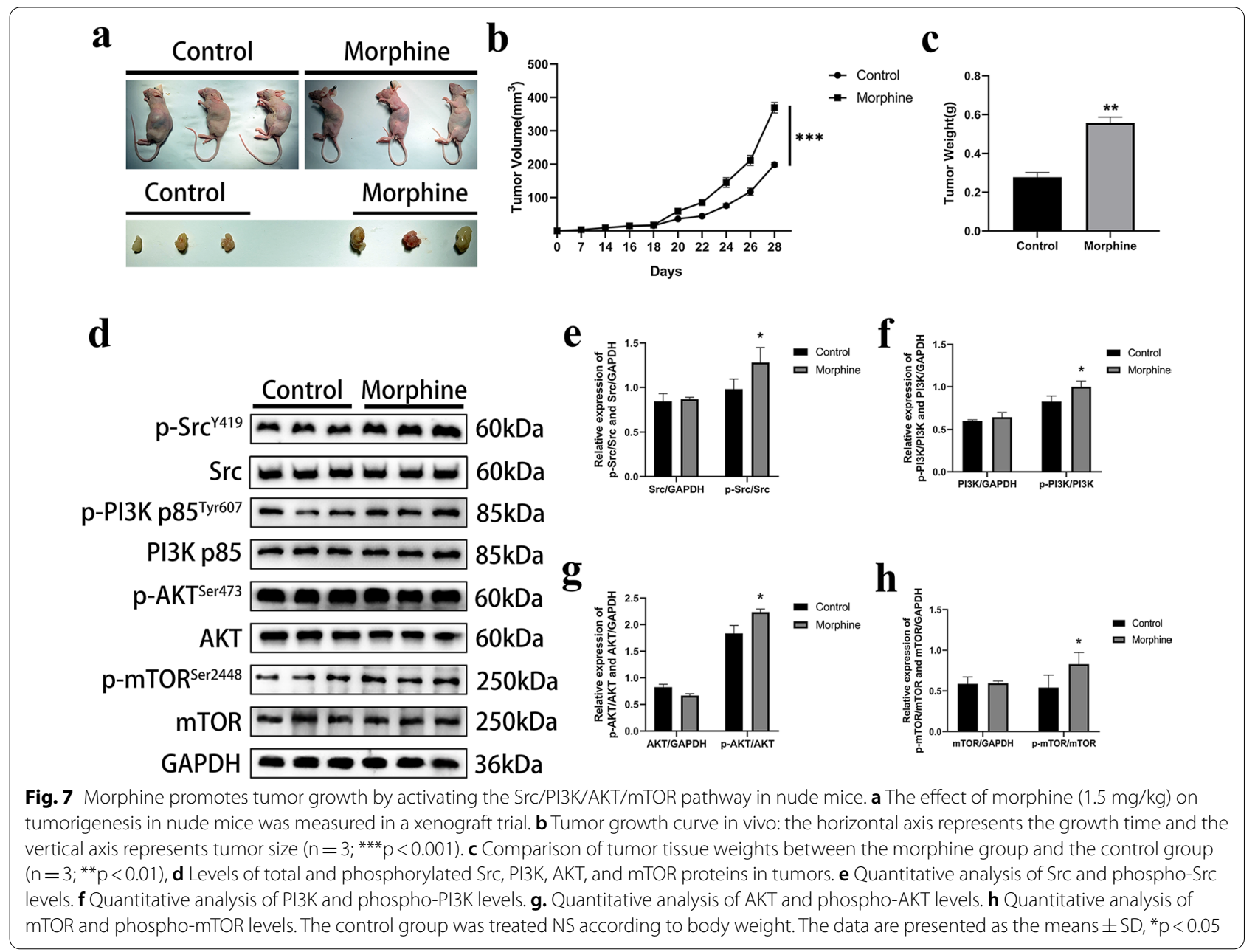

PI3K/AKT/mTOR signaling pathway, one of the most important intracellular signaling pathways, affects the state of downstream effector molecules in many ways. It plays a key role in regulating malignant cell behavior and is closely related to the occurrence and development of a variety of human tumors [46]. In our study, morphine significantly increased the activation of the Src/PI3K/AKT and mTOR proteins, as evidenced by increased phosphorylation of these proteins. In addition, morphine-induced cell proliferation and migration were significantly inhibited after intervention with the MOR antagonist MNTX and the Src inhibitor PP1. MNTX, PP1 and the PI3K/ AKT inhibitor deguelin antagonized the antiapoptotic effect of morphine. In contrast to previous studies [17,
18], we found that MNTX and PP1 treatment alone had no effect on the viability of $\mathrm{H} 460$ cells, but they exerted an effect in the presence of morphine. We speculated that the continuous effect of morphine is a prerequisite for the effects of MNTX and PP1 and that morphine plays a role in promoting the activation of the MOR and Src/PI3K/ AKT/mTOR pathways in $\mathrm{H} 460$ cells. Then, we confirmed that morphine promoted the proliferation and migration of $\mathrm{H} 460$ cells through the MOR/Src/PI3K/AKT/mTOR pathway.

Therefore, morphine binds specifically to MOR and subsequently activates the Src/PI3K/AKT/mTOR pathway through a cascade effect at low concentrations, thus promoting the proliferation, migration, and invasion of H460 non-small cell lung cancer cells and inhibiting 


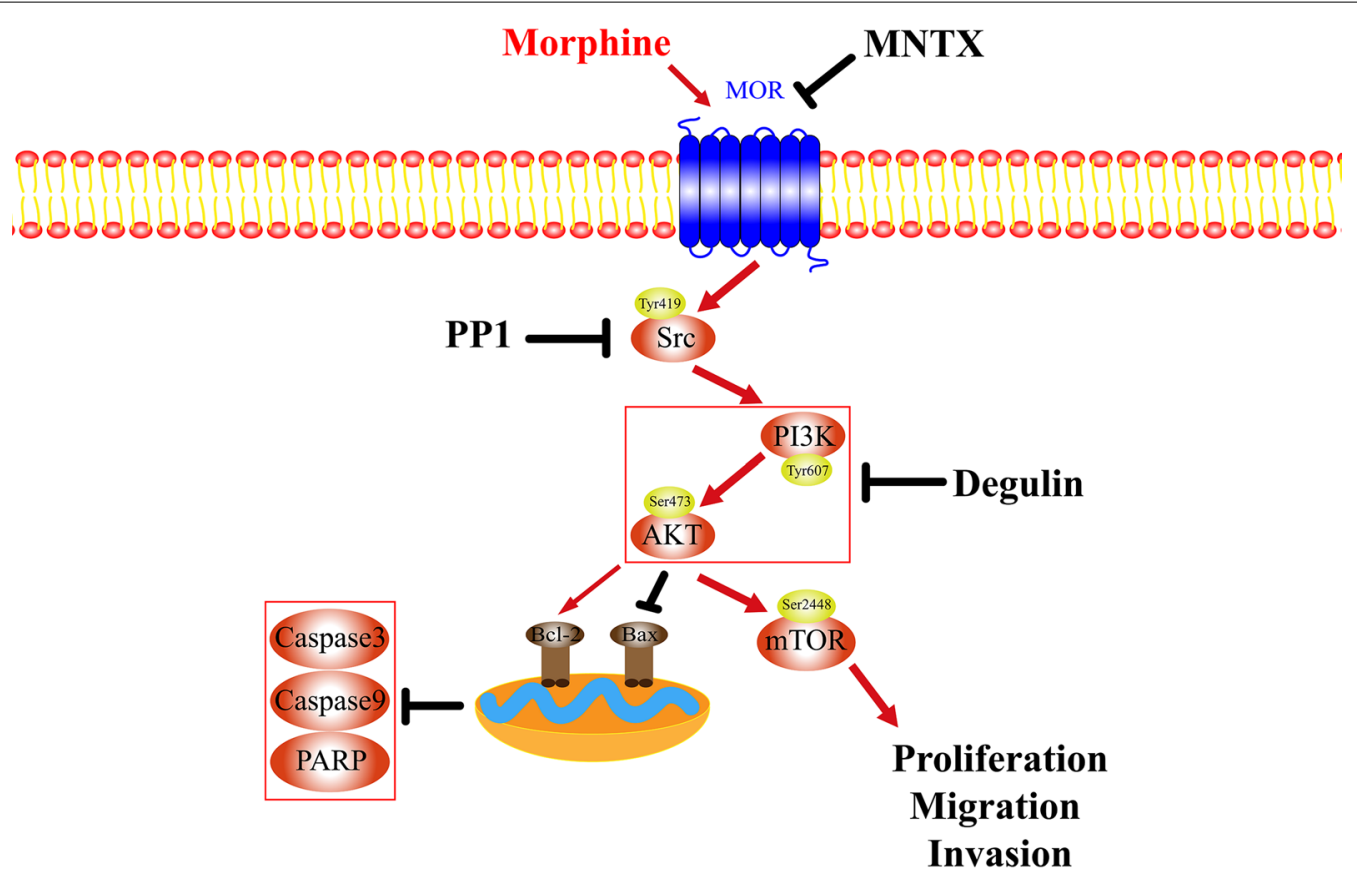

Fig. 8 Schematic model illustrating the potential pathway associated with morphine-induced malignant biological behavior in $\mathrm{H} 460$ cells. Morphine acts on an MOR located on the H460 cell membrane, leading to Src activation. The activation of Src increases the levels of phospho-PI3K ${ }^{\mathrm{Ty} r 607}$ and phospho-AKT ${ }^{\mathrm{Se} 473}$, which is inhibited by PP1. Src activates the PI3K/AKT pathway, leading to an increase in the expression of proapoptotic factors and a decrease in the expression of antiapoptotic factors. These changes induce Caspase-dependent and mitochondria-mediated apoptotic cell death, which was inhibited by deguelin. Activation of the PI3K/AKT pathway further activates mTOR, leading to an upregulation of factors that induce cell proliferation, migration, and invasion

apoptosis in vitro (Fig. 8). Subcutaneous injection of $1.5 \mathrm{mg} / \mathrm{kg}$ morphine did not promote tumor formation in nude mice but significantly stimulated tumor growth.

\section{Conclusions}

Morphine promotes the malignant biological behavior of H460 non-small cell lung cancer cells in vivo and in vitro, which provides an experimental basis for the use of morphine in the treatment of pain in patients with advanced lung cancer.

\footnotetext{
Abbreviations

AKT: Protein kinase B; ANOVA: Analysis of variance; AV: Annexin V-FITC; CCK-8: Cell Counting Kit-8; DMSO: Dimethyl sulfoxide; DOR: $\delta$-Opioid receptor; ECL: Enhanced chemiluminescence; KOR: k-Opioid receptor; MNTX: MethyInaltrexone; MOR: $\mu$-Opioid receptor; mTOR: Mammalian target of rapamycin; NSCLC: Non-small-cell lung cancer; NS: Normal saline; PARP: Poly ADP-ribose polymerase; PI: Propidium iodide; PI3K: Phosphoinositide 3 kinase; PP1: Protein phosphatase 1; PVDF: Polyvinylidene fluoride; RIPA: Radioimmunoprecipitation assay; SDS-PAGE: Sodium dodecyl sulfate-polyacrylamide gel electrophoresis; Src: Rous sarcoma oncogene cellular homolog; TBST: Tris-buffered saline with Tween.
}

\section{Supplementary Information}

The online version contains supplementary material available at https://doi. org/10.1186/s12935-021-02334-8.

Additional file 1: Figure S1. Preliminary experiment assessing the effects of morphine and MNTX on the proliferation of H460 cells. We preliminarily verified the effects of previously reported concentrations of morphine and MNTX on the proliferation of $\mathrm{H} 460$ cells, and the difference was not statistically significant (Fig. S1a; $p>0.05$ ). Then, we increased the drug concentration, and $300 \mu \mathrm{M}$ morphine promoted the proliferation of $\mathrm{H} 460$ cells (Fig. S1 b; $p<0.01$ ), but MNTX did not induce a significant difference (Fig. S1 b; $\mathbf{p}>0.05$ ). Figure $\mathbf{S 2}$. The expression of apoptosis-related proteins in tumors from nude mice. In the group subcutaneously injected with morphine, Bcl-2 expression was increased, while the levels of Bax, cleaved Caspase-3, cleaved Caspase-9 and cleaved PARP proteins were decreased. Thus, morphine also inhibits the expression of proapoptotic proteins in vivo. All data are presented as the means \pm SEM, ${ }^{*} p<0.05,{ }^{* *} p<0.01$ compared with the control group.

\section{Acknowledgments}

Not applicable.

\section{Authors' contributions}

$J L$ and FK conceived the project, designed the research, supervised the experiments, and wrote the manuscript. XL designed the research, performed the experiments, analyzed the data, and wrote the manuscript. JY contributed to collating and analyzing the new data and revising the manuscript. CY, MH and $\mathrm{XH}$ contributed to revising the manuscript. All authors have read and approved the final submitted manuscript. 


\section{Funding}

This work was financially supported by Fundamental Research Funds for Central Universities of the University of Science and Technology of China (USTC) (WK9110000045), Fundamental Research Funds for Central Universities of the University of Science and Technology of China (USTC) (WK9110000059), and the Natural Science Foundation of Anhui Province (1908085MH251).

\section{Availability of data and materials}

The data used in the current study are available from the corresponding author upon reasonable request.

\section{Declarations}

\section{Ethical approval and consent to participate}

The present study was approved by the Ethics Committee of Anhui Province Hospital.

\section{Consent for publication}

Not applicable.

\section{Competing interests}

The authors have no competing interests to declare.

Received: 8 September 2021 Accepted: 10 November 2021

Published online: 25 November 2021

\section{References}

1. Siegel RL, Miller KD, Fuchs HE, Jemal A. Cancer statistics, 2021. CA Cancer J Clin. 2021;71(1):7-33.

2. Sung H, Ferlay J, Siegel RL, Laversanne M, Soerjomataram I, Jemal A, Bray F. Global cancer statistics 2020: GLOBOCAN estimates of incidence and mortality worldwide for 36 cancers in 185 countries. CA Cancer J Clin. 2021. https://doi.org/10.3322/caac.21660.

3. Turner MC, Andersen ZJ, Baccarelli A, Diver WR, Gapstur SM, Pope CA 3rd, Prada D, Samet J, Thurston G, Cohen A. Outdoor air pollution and cancer: an overview of the current evidence and public health recommendations. CA Cancer J Clin. 2020. https://doi.org/10.3322/caac.21632.

4. Nersesyan $\mathrm{H}$, Slavin KV. Current aproach to cancer pain management: availability and implications of different treatment options. Ther Clin Risk Manag. 2007;3(3):381-400.

5. Smith TJ, Staats PS, Deer T, Stearns LJ, Rauck RL, Boortz-Marx RL, Buchser E, Català E, Bryce DA, Coyne PJ, et al. Randomized clinical trial of an implantable drug delivery system compared with comprehensive medical management for refractory cancer pain: impact on pain, drug-related toxicity, and survival. J Clin Oncol. 2002;20(19):4040-9.

6. Maher DP, Wong W, White PF, McKenna R, Rosner H, Shamloo B, Louy C, Wender R, Yumul R, Zhang V. Association of increased postoperative opioid administration with non-small-cell lung cancer recurrence: a retrospective analysis. Br J Anaesth. 2014;113:i88-94.

7. Nishiwada T, Kawaraguchi Y, Uemura K, Kawaguchi M. Morphine inhibits cell viability and growth via suppression of vascular endothelial growth factor in human oral cancer HSC-3 cells. J Anesth. 2019;33(3):408-15.

8. Chen Y, Qin Y, Li L, Chen J, Zhang X, Xie Y. Morphine can inhibit the growth of breast cancer MCF-7 cells by arresting the cell cycle and inducing apoptosis. Biol Pharm Bull. 2017:40(10):1686-92.

9. Luo J, Chen Y, Xu Y, Tang M, Zhang X. Morphine contributed to the deterioration of cancer via miR-543/MARCKS/FcyR-mediated phagocytosis pathway. J Pharm Pharmacol. 2019;71(10):1584-98.

10. Gach K, Wyrebska A, Fichna J, Janecka A. The role of morphine in regulation of cancer cell growth. Naunyn Schmiedebergs Arch Pharmacol. 2011;384(3):221-30.

11. Bimonte S, Barbieri A, Rea D, Palma G, Luciano A, Cuomo A, Arra C, Izzo F. Morphine promotes tumor angiogenesis and increases breast cancer progression. Biomed Res Int. 2015;2015: 161508.

12. Trescot AM, Datta S, Lee M, Hansen H. Opioid pharmacology. Pain Physician. 2008;11(2 Suppl):S133-53.

13. Zylla D, Gourley BL, Vang D, Jackson S, Boatman S, Lindgren B, Kuskowski MA, Le C, Gupta K, Gupta P. Opioid requirement, opioid receptor expression, and clinical outcomes in patients with advanced prostate cancer. Cancer. 2013;119(23):4103-10.

14. Zhang YF, Xu QX, Liao LD, Xu XE, Wu JY, Wu ZY, Shen JH, Li EM, Xu LY. Association of mu-opioid receptor expression with lymph node metastasis in esophageal squamous cell carcinoma. Dis Esophagus. 2015;28(2):196-203.

15. Zhang H, Sun M, Zhou D, Gorur A, Sun Z, Zeng W, Cata JP, Chen W, Miao C. Increased mu-opioid receptor expression is associated with reduced disease-free and overall survival in laryngeal squamous cell carcinoma. Br J Anaesth. 2020;125(5):722-9.

16. Singleton PA, Mirzapoiazova T, Hasina R, Salgia R, Moss J. Increased mu-opioid receptor expression in metastatic lung cancer. $\mathrm{Br} J$ Anaesth. 2014;113(Suppl 1):i103-108.

17. Lennon FE, Mirzapoiazova T, Mambetsariev B, Poroyko VA, Salgia R, Moss J, Singleton PA. The Mu opioid receptor promotes opioid and growth factor-induced proliferation, migration and Epithelial Mesenchymal Transition (EMT) in human lung cancer. PLoS ONE. 2014;9(3): e91577.

18. Tatton L, Morley GM, Chopra R, Khwaja A. The Src-selective kinase inhibitor PP1 also inhibits Kit and Bcr-Abl tyrosine kinases. J Biol Chem. 2003;278(7):4847-53.

19. Chun KH, Kosmeder JW 2nd, Sun S, Pezzuto JM, Lotan R, Hong WK, Lee HY. Effects of deguelin on the phosphatidylinositol 3-kinase/Akt pathway and apoptosis in premalignant human bronchial epithelial cells. J Natl Cancer Inst. 2003;95(4):291-302.

20. Barra F, Evangelisti G, Ferro Desideri L, Di Domenico S, Ferraioli D, Vellone VG, De Cian F, Ferrero S. Investigational PI3K/AKT/mTOR inhibitors in development for endometrial cancer. Expert Opin Investig Drugs. 2019;28(2):131-42.

21. Laplante M, Sabatini DM. mTOR signaling in growth control and disease. Cell. 2012;149(2):274-93.

22. Wang Z, Ma B, Li H, Xiao X, Zhou W, Liu F, Zhang B, Zhu M, Yang Q, Zeng $Y$, et al. Protein $4.1 \mathrm{~N}$ acts as a potential tumor suppressor linking PP1 to JNK-C-Jun pathway regulation in NSCLC. Oncotarget. 2016;7(1):509-23.

23. Xu S, Tang J, Wang C, Liu J, Fu Y, Luo Y. CXCR7 promotes melanoma tumorigenesis via Src kinase signaling. Cell Death Dis. 2019;10(3):191.

24. Köhn M. Turn and face the strange: a new view on phosphatases. ACS Cent Sci. 2020;6(4):467-77.

25. Wang A, Wang W, Chen Y, Ma F, Wei X, Bi Y. Deguelin induces PUMAmediated apoptosis and promotes sensitivity of lung cancer cells (LCCS) to doxorubicin (Dox). Mol Cell Biochem. 2018;442(1-2):177-86.

26. Hsu YC, Chiang JH, Yu CS, Hsia TC, Wu RS, Lien JC, Lai KC, Yu FS, Chung JG. Antitumor effects of deguelin on $\mathrm{H} 460$ human lung cancer cells in vitro and in vivo: roles of apoptotic cell death and $\mathrm{H} 460$ tumor xenografts model. Environ Toxicol. 2017;32(1):84-98.

27. Hsiao Y, Fan M, Huang A, Lien J, Lin J, Chen J, Hsia T, Wu R, Chung J. Deguelin impairs cell adhesion, migration and invasion of human lung cancer cells through the NF-kB signaling pathways. Am J Chin Med. 2018;46(1):209-29.

28. Gupta K, Kshirsagar S, Chang L, Schwartz R, Law P-Y, Yee D, Hebbel RP. Morphine stimulates angiogenesis by activating proangiogenic and survival-promoting signaling and promotes breast tumor growth. Can Res. 2002;62(15):4491-8.

29. Murillo G, Salti Gl, Kosmeder JW, Pezzuto JM, Mehta RG. Deguelin inhibits the growth of colon cancer cells through the induction of apoptosis and cell cycle arrest. Eur J Cancer. 2002;38(18):2446-54.

30. Bandieri E, Romero M, Ripamonti Cl, Artioli F, Sichetti D, Fanizza C, Santini D, Cavanna L, Melotti B, Conte PF, et al. Randomized trial of low-dose morphine versus weak opioids in moderate cancer pain. J Clin Oncol. 2016;34(5):436-42.

31. Nguyen J, Luk K, Vang D, Soto W, Vincent L, Robiner S, Saavedra R, Li Y, Gupta P, Gupta K. Morphine stimulates cancer progression and mast cell activation and impairs survival in transgenic mice with breast cancer. Br J Anaesth. 2014;113(Suppl 1):i4-13.

32. Harimaya Y, Koizumi K, Andoh T, Nojima H, Kuraishi Y, Saiki I. Potential ability of morphine to inhibit the adhesion, invasion and metastasis of metastatic colon 26-L5 carcinoma cells. Cancer Lett. 2002;187(1-2):121-7.

33. Hsiao P-N, Chang M-C, Cheng W-F, Chen C-A, Lin H-W, Hsieh C-Y, Sun W-Z. Morphine induces apoptosis of human endothelial cells through nitric oxide and reactive oxygen species pathways. Toxicology. 2009;256(1-2):83-91. 
34. Koodie L, Ramakrishnan S, Roy S. Morphine suppresses tumor angiogenesis through a HIF-1alpha/p38MAPK pathway. Am J Pathol. 2010;177(2):984-97.

35. Chen C, Farooqui M, Gupta K. Morphine stimulates vascular endothelial growth factor-like signaling in mouse retinal endothelial cells. Curr Neurovasc Res. 2006;3(3):171-80.

36. Klepstad P, Kaasa S, Borchgrevink PC. Start of oral morphine to cancer patients: effective serum morphine concentrations and contribution from morphine-6-glucuronide to the analgesia produced by morphine. Eur J Clin Pharmacol. 2000;55(10):713-9.

37. Boland JW, Pockley AG. Influence of opioids on immune function in patients with cancer pain: from bench to bedside. Br J Pharmacol. 2018;175(14):2726-36

38. Bagnato G, Leopizzi M, Urciuoli E, Peruzzi B. Nuclear functions of the tyrosine kinase Src. Int J Mol Sci. 2020. https://doi.org/10.3390/ijms2 1082675.

39. Matozaki T, Kotani T, Murata Y, Saito Y. Roles of Src family kinase, Ras, and mTOR signaling in intestinal epithelial homeostasis and tumorigenesis. Cancer Sci. 2021;112(1):16-21.

40. Hermida-Prado F, Granda-Díaz R, Del-Río-lbisate N, Villaronga MÁ, Allonca E, Garmendia I, Montuenga LM, Rodríguez R, Vallina A, Alvarez-Marcos $C$, et al. The differential impact of SRC expression on the prognosis of patients with head and neck squamous cell carcinoma. Cancers. 2019. https://doi.org/10.3390/cancers11111644.

41. Tsao AS, Lin H, Carter BW, Lee JJ, Rice D, Vaporcyan A, Swisher S, Mehran $R$, Heymach J, Nilsson M, et al. Biomarker-integrated neoadjuvant dasatinib trial in resectable malignant pleural mesothelioma. J Thorac Oncol. 2018;13(2):246-57.

42. Hassoun SM, Abdel-Rahman N, Eladl El, El-Shishtawy MM. Antiangiogenic activity of vitexicarpine in experimentally induced hepatocellular carcinoma: impact on vascular endothelial growth factor pathway. Tumour Biol. 2017;39(6):1010428317707376.

43. Wang D, Yang T, Liu J, Liu Y, Xing N, He J, Yang J, Ai Y. Propofol inhibits the migration and invasion of glioma cells by blocking the PI3K/AKT pathway through miR-206/ROCK1 axis. Onco Targets Ther. 2020;13:361-70.

44. Kim CS, Kim IJ, Choi JS, Bae EH, Ma SK, Kim SW. Tamoxifen ameliorates obstructive nephropathy through Src and the PI3K/Akt/mTOR pathway. Biol Cell. 2019;111(1):18-27.

45. Rong L, Li Z, Leng X, Li H, Ma Y, Chen Y, Song F. Salidroside induces apoptosis and protective autophagy in human gastric cancer AGS cells through the PI3K/Akt/mTOR pathway. Biomed Pharmacother. 2020;122: 109726.

46. Balakrishnan K, Peluso M, Fu M, Rosin NY, Burger JA, Wierda WG, Keating MJ, Faia K, O'Brien S, Kutok JL, et al. The phosphoinositide-3-kinase (PI3K)delta and gamma inhibitor, IPI-145 (Duvelisib), overcomes signals from the PI3K/AKT/S6 pathway and promotes apoptosis in CLL. Leukemia. 2015;29(9):1811-22.

\section{Publisher's Note}

Springer Nature remains neutral with regard to jurisdictional claims in published maps and institutional affiliations.
Ready to submit your research? Choose BMC and benefit from:

- fast, convenient online submission

- thorough peer review by experienced researchers in your field

- rapid publication on acceptance

- support for research data, including large and complex data types

- gold Open Access which fosters wider collaboration and increased citations

- maximum visibility for your research: over $100 \mathrm{M}$ website views per year

At BMC, research is always in progress.

Learn more biomedcentral.com/submissions 